\title{
鉛フリーはんだ接合部の応力・非線形ひずみ振幅評価に及ぼす 硬化則の影響
}

\author{
金 道㦪 ${ }^{*}$ 于 強**，涉谷 忠弘 ${ }^{* *}$ ，白鳥 正樹 ${ }^{* *}$
}

\section{Nonlinear Behavior Study on Effect of Hardening Rule of Lead Free Solder Joint}

Do-Seop KIM* ${ }^{*}$ Qiang $\mathrm{YU}^{* *}$, Tadahiro SHIBUTANI** and Masaki SHIRATORI**

*横浜国立大学大学院工学府システム統合工学専攻機械システム工学コース（テ240-8501 神奈川県横浜市保土ヶ谷区常盤台 79-5）

**横浜国立大学大学院工学研究院システムの創生部門システムのデザイン分野（†240-8501 神奈川県横浜市保土ヶ谷区常盤台 79-5）

* Department of Mechanical Engineering, Division of Systems Integration, Graduate School of Engineering, Yokohama National University (79-5 Tokiwadai, Hodogaya-ku, Yokohama-shi, Kanagawa 240-8501)

**Department of Systems Design, Division of Systems Research, Faculty of Engineering, Yokohama National University (79-5 Tokiwadai, Hodogaya-ku, Yokohamashi, Kanagawa 240-8501)

\begin{abstract}
概要＼cjkstart本研究では鉛フリーはんだ接合部の機械的疲労試験と有限要素法(FEM)解析を用いて，鉛フリーはんだ接合部の応 力・非線形ひずみの評価においての硬化則の影響を調へた。機械的せん断疲労試験の結果から, Sn-3.5Ag-0.75Cu と Sn-8Zn-3Bi はんだは移動硬化の硬化特性を示していることが確認された。機械的負荷と温度サイクル負荷の解析において，等方硬化則と 移動硬化則による非線形ひずみ振幅の誤差が大きくても $15 \%$ 程度で，接合部の疲労寿命評価にそれれよ゙大きな影響を与えな いと考えられる。また，応力の評価において，機械的負荷解析では両硬化則の誤差が $40 \%$ ま大゙きくなる。しかし，機械的 負荷解析と温度サイクル解析において移動硬化則を適用し，負荷時にはクリープを考慮せず保持時間のみクリープを考慮した 弾塑性・クリープ解析を行うと, 収束性に問題なく応力・非線形ひずみの評価における誤差が $10 \%$ 以下の精度のよい結果が 得られる。
\end{abstract}

\begin{abstract}
In this paper, the effect of hardening rule on stress and nonlinear strain estimation for lead free solder joint is examined using mechanical fatigue test and FEM analysis. From the results of mechanical shear cyclic test, it turns out that $\mathrm{Sn}-3.5 \mathrm{Ag}-75 \mathrm{Cu}$ and $\mathrm{Sn}-8 \mathrm{Zn}-3 \mathrm{Bi}$ solder show remarkable hardening characteristic of kinematic hardening. Based upon the FEM analytical results with mechanical and thermal cyclic loading conditions, it is shown that the hardening rule may cause $15 \%$ error at the most in evaluation of non-linear strain in solder joint and this degree of error will not significantly affect the fatigue strength evaluation of solder joint. And the error of maximum stress in solder joint between the both hardening rules increases to $40 \%$ for the mechanical loading case. However, the error in the evaluation of stress and nonlinear strain is $10 \%$ or less, when elasto-plasticity and creep analysis in which considered the kinematic hardening law in loading and holding time, but the creep only in holding time is carried out.
\end{abstract}

Key Words: Lead-Free Solder, Mechanical Shear Fatigue Test, Isotropic Hardening Rule, Kinematic Hardening Rule, FEM

\section{1. 緒 言}

従来の $\mathrm{Sn}-37 \mathrm{~Pb}$ 共晶はんだは，比較的変形しやすく，使 用温度環境において顕著なクリープ特性を示している。 $\mathrm{Sn}-37 \mathrm{~Pb}$ 共晶はんだを用いた接合部に温度サイクルまたは 機械的繰り返し負荷が与えられた場合は，疲労き裂がはん だ側に発生して破壊するのが主な破壊モードであるため, はんだ接合部の疲労寿命評価法としてはんだ接合部に発生 する非線形ひずみ（塑性ひずみとクリープひずみ）を評価 する方法が主に研究されている1) 4)。Fig. 1 は各種はんだ材 の応力-ひずみ関係を示している5,6)。最む低い引張強さを 示しているのが $\mathrm{Sn}-37 \mathrm{~Pb}$ 共晶はんだで, 他の 3 つは鉛フリー
はんだである。鉛フリーはんだは $\mathrm{Sn}-37 \mathrm{~Pb}$ 共晶はんだと比 べて, 降伏後の加工硬化が顕著であるため, はんだ接合端 部に発生する応力が高くなる。鉛フリーはんだを用いたは んだ接合部においては，この高い応力集中によってはんだ 接合界面にき裂が発生・進展する可能性が高くなるため, はんだ接合部の疲労寿命予測においてははんだ接合部の非 線形ひずみの評価とともに界面において生じる応力の評価 も重要である7)。

材料が降伏した後，さらに負荷を加えると一般的には硬 化しながら塑性変形が進行する。繰り返し負荷が与えられ たときの硬化特性には等方硬化と移動硬化などがある8)。 鉛フリーはんだと $\mathrm{S} n-37 \mathrm{~Pb}$ 共晶はんだは移動硬化の硬化特 


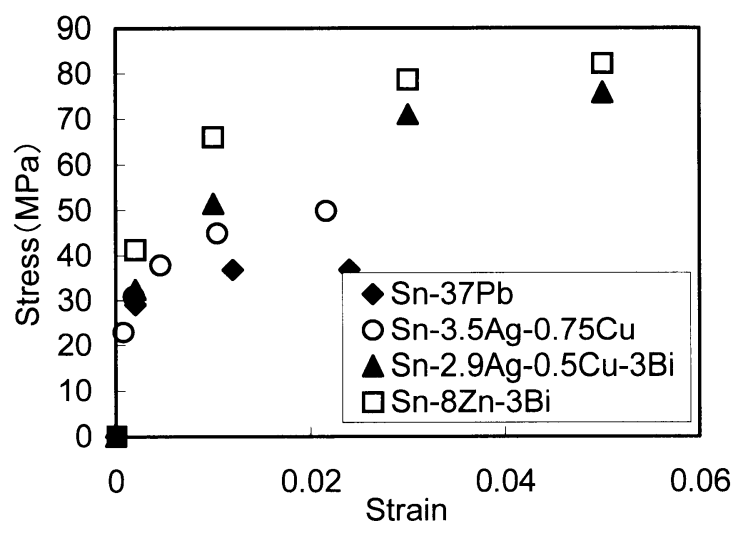

Fig. 1 Stress-strain curve of each solder material $\left(20^{\circ} \mathrm{C}\right.$, Strain rate: $\left.0.004 \mathrm{~s}^{-1}\right)$

性を示している。Sn-37Pb 共晶はんだの場合は加工硬化が 小さく, 温度サイクルにおいてはクリープが主たる変形と なるため, 加工硬化よりクリープ変形が重要である。すな わち，有限要素法解析でクリープ挙動を評価すれば，はん だ接合部の応力・非線形ひずみの評価に対する加工硬化の 影響は無視できる。一方，鉛フリーはんだの場合は材料の 降伏後, 加工硬化が顕著であるためはんだ接合部の応力・ 非線形ひずみの評価においての硬化則の影響を十分検討す る必要がある。しかし, 有限要素法解析において移動硬化 則とクリープ特性を同時に考慮すると, 収束性が悪くなり 解析時間が長くなることがよくある。

本研究では $\mathrm{Sn}-3.5 \mathrm{Ag}-0.75 \mathrm{Cu}, \mathrm{Sn}-8 \mathrm{Zn}-3 \mathrm{Bi}$ 鉛フリーはん だ接合部の機械的せん断疲労試験を行い，各はんだ材の硬 化特性を調べた。また, 有限要素法(FEM) 解析を用いて, 鉛フリーはんだ接合部の応力・非線形ひずみ評価において の各硬化則の影響を調べ，鉛フリーはんだ接合部の応力・ 非線形ひずみの評価方法について検討を行った。

\section{Sn-3.5Ag-0.75Cu と Sn-8Zn-3Bi 鉛フリーはんだ の硬化特性}

鉛フリーはんだの中で多く使用されている $\mathrm{Sn}-3.5 \mathrm{Ag}-$ 0.75Cu，Sn-8Zn-3Bi鉛フリーはんだを用いたBGA はんだ接 合部のせん断疲労試験を行い, $\mathrm{Sn}-3.5 \mathrm{Ag}-0.75 \mathrm{Cu}$ と $\mathrm{Sn}-$

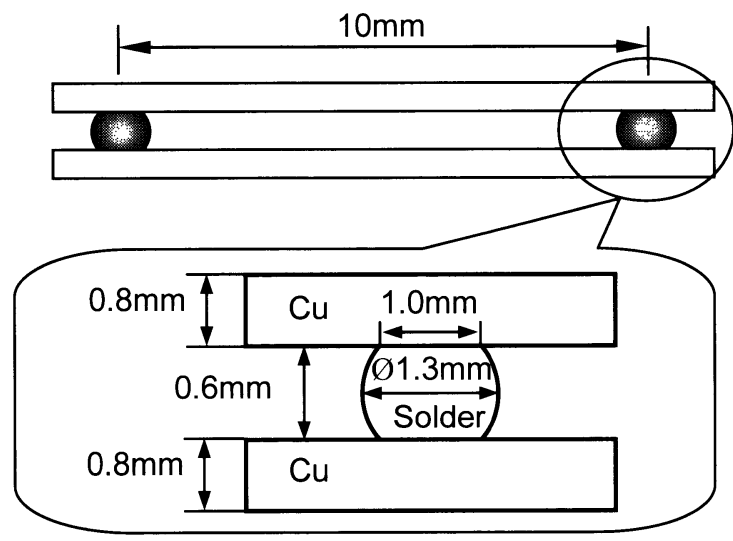

Fig. 2 Dimensions of specimen used in this study
8Zn-3Bi はんだの硬化特性について調べた。BGA 試験片の概 要をFig. 2 に示す。上下銅板の間に鉛フリーはんだボール

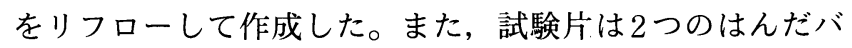
ンプを有する。機械的せん断疲労試験機の概要を Fig. 3 に 示す。試験片を上下面治具に接着固定して下の治具は完全 固定し，上の治具にせん断方向の強制変位を与えて試験を 行った。強制変位はFig. 4に示すように, 保持を設けてい ない三角波（変位振幅 $\Delta \delta: 7 \mu \mathrm{m}, 0.01 \mathrm{~Hz}$ ） と最大変位お よび最小変位時に 15 分間の保持時間を設けた台形波を与え て試験を行った。また，はんだ材料の硬化特性を特定する には応力を調べる必要があるが，実際はんだ接合部に発生 する応力の測定は難しいので, 試験においては, 解析結果 との比較のためにはんだ接合部の反力を測定した。

まず，三角波の強制変位（変位振幅 $\Delta \delta: 7 \mu \mathrm{m}, 0.01 \mathrm{~Hz}$ ） を与えた場合の最初の 2 サイクルの結果を Fig. 5-(a)に示す。

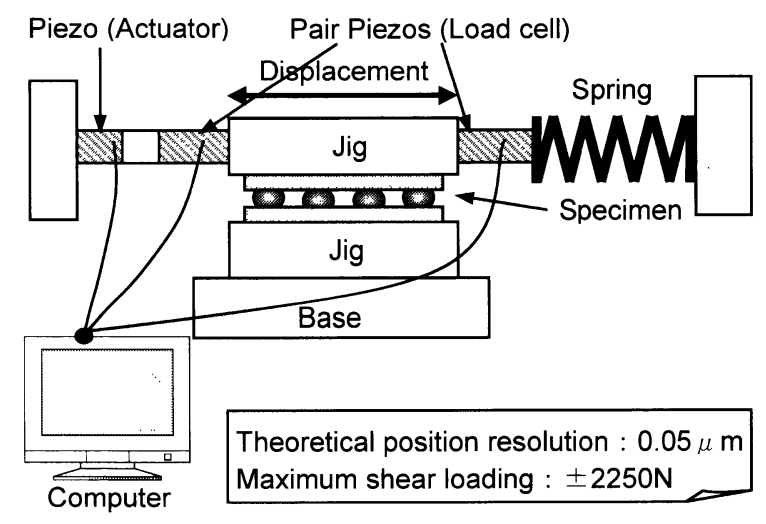

Fig. 3 Isothermal mechanical fatigue test machine

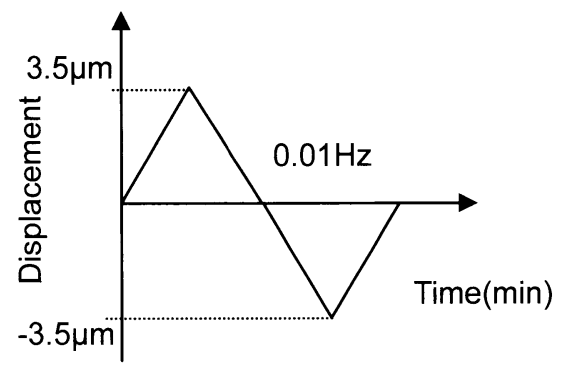

(a) Triangular wave

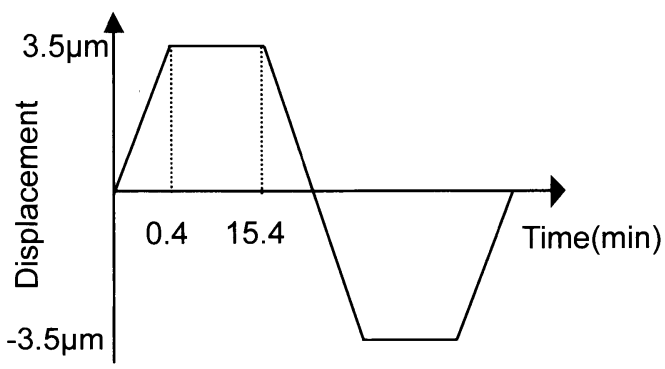

(b) Trapezoid wave with 15 minutes holding time

Fig. 4 Forced displacement in mechanical fatigue test 


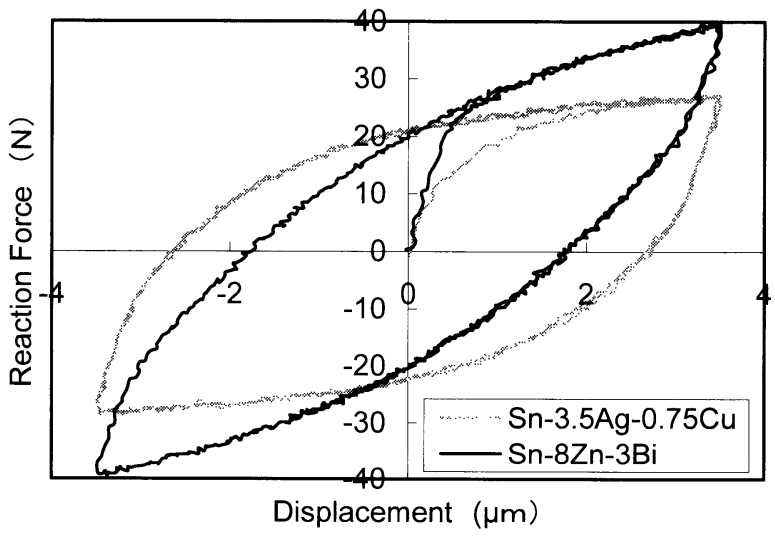

(a) Triangular wave

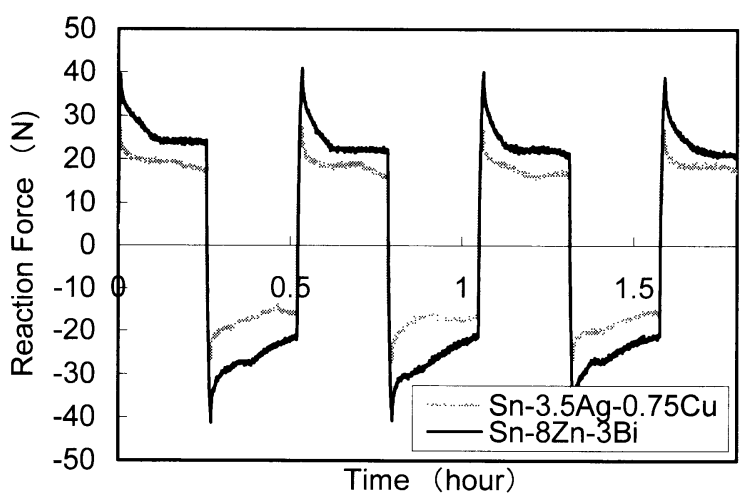

(b) Trapezoid wave with 15 minutes holding time

Fig. 5 Result of the mechanical shear fatigue test

横軸は強制変位，縦軸ははんだ接合部の反力を示してい る。Sn-8Zn-3Bi はんだでは Sn-3.5Ag-0.75Cuはんだに比べ 高い加工硬化を示し，はんだ接合部の反力屯大きくなる。 Fig. 5-(a)から Sn-3.5Ag-0.75Cu と Sn-8Zn-3Bi はんだ材にお いては機械的負荷が繰り返されても反力が上昇せず，一定 值を保っている。これは, Sn-3.5Ag-0.75Cu と Sn-8Zn-3Bi はんだが移動硬化の硬化特性を有することを意味する。

変位がピーク值に達した後に 15 分間保持時間を設けた試 験結果（変位振幅 $\Delta \delta: 7 \mu \mathrm{m}$ ）をFig. 5-(b)に示す。保持時 間に生じる応力緩和を示すために，はんだ接合部に生じる 反力と時間の関係を示している。保持時間において反力の 低下には若干のばらつきがあるが，反力の幅は保持時間の ない結果と同様にほぼ一定値を保っている。この保持時間 において反力の微少変動は試験機の精度の問題であると思 われる。

\section{3. 応力・非線形ひずみ評価に及ぼす硬化則の影響}

本研究では汎用 FEM (Finite Element Method)解析ソフト ABAQUS を用いて実験と同じ条件の弾塑性・クリープ解析 を行い，はんだ接合部の応力・非線形ひずみに対する等方 硬化と移動硬化の影響について調べた。また，より使用環 境に近い熱疲労サイクル解析においても同様な検討を行っ た。本研究で行った解析では解析の簡略化のために塑性特 性をFig. 6 に示すように 2 直線で近似して適用した。塑性

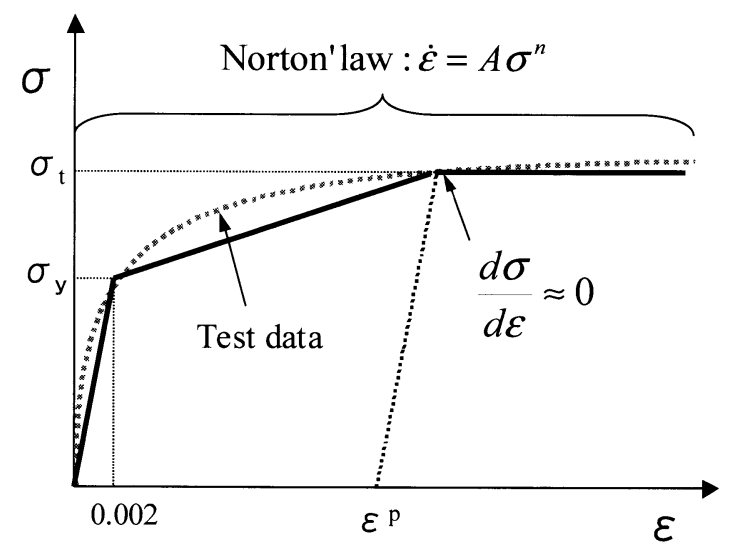

Fig. 6 Plasticity model and creep model used in analysis

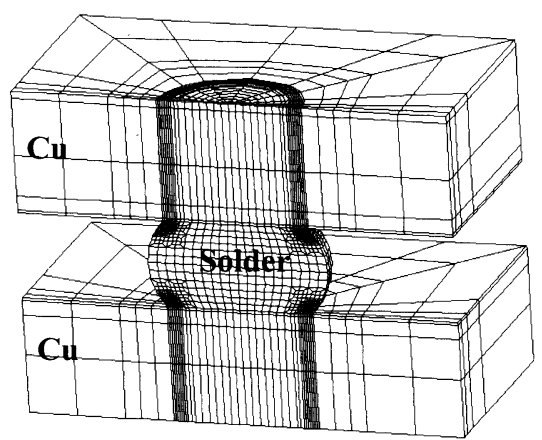

Fig. 7 Analysis model for mechanical loading

ひずみ $\varepsilon^{p}$ はひずみの増分に対して応力の増分がほぼゼロに 近い值を取っている。塑性変形がなければ，応力はNorton 則に支配されるが, 塑性変形とクリープ変形が同時に発生 した場合は，両方の挙動が相互に作用し合うため，連成し た構成式をとくことになる。収束性に関しては有限要素ソ フトによって变わるが，一般的には材料試験のひずみ速度 と実際のはんだバンプに発生するひずみ速度が大きく違わ なければ問題ないと思われる。

\section{1 機械的せん断疲労解析}

機械的せん断疲労解析に用いた解析モデルを Fig. 7 に示 す。解析モデルは試験片の対称性を考慮し，実験で用いた 試験片の $1 / 4$ モデルを作成した。また，解析で使用した $\mathrm{Sn}-3.5 \mathrm{Ag}-0.75 \mathrm{Cu}$ と $\mathrm{Sn}-8 \mathrm{Zn}-3 \mathrm{Bi}$ はんだ材の物性值を Table 1 に示す6),9)。Table 1 に示す Norton 則の定義は式(1)に示すク リープひずみ速度と負荷応力の関係を表すものである。 $\dot{\varepsilon}_{c}=A \sigma^{n}$

$A$ はクリープ定数，nはクリープ硬化指数である。塑性 特性は 2 直線近似で解析を行った。強制変位は実験と同様 に保持のない三角波形と 15 分間の保持時間を設けた台形波 形を用い，5サイクルまで解析を行った。解析において強 制変位を負荷するときもクリープ変形を考慮した。また， はんだ接合部に発生する最大相当応力と非線形ひずみの代 表值としては，Fig. 8に示すように要素サイズの影響を避 けるため, 接合端部から $50 \mu \mathrm{m}$ 入ったところの積分点の値 
Table 1. Material properties of $\mathrm{Sn}-3.5 \mathrm{Ag}-0.75 \mathrm{Cu}$ and $\mathrm{Sn}-8 \mathrm{Zn}-3 \mathrm{Bi}$ solder

\begin{tabular}{c|c|c|c|c|c}
\hline \multicolumn{2}{c|}{ Material } & \multicolumn{2}{c|}{ Sn-3.5Ag-0.75Cu } & \multicolumn{2}{c}{ Sn-8Zn-3Bi } \\
\hline \multicolumn{2}{c|}{ Elastic Modulus (MPa) } & \multicolumn{2}{|c|}{37.4} & \multicolumn{2}{c}{50} \\
\hline \multicolumn{2}{c|}{ Poisson's rate } & \multicolumn{2}{|c|}{0.41} & \multicolumn{2}{c}{0.3} \\
\hline \multirow{2}{*}{$\begin{array}{c}\text { Plastic } \\
\text { property }\end{array}$} & Strain & 0.0 & 0.0216 & 0.0 & 0.03 \\
\cline { 2 - 6 } & Stress (MPa) & 28.4 & 49.8 & 41 & 78 \\
\hline \multirow{2}{*}{$\begin{array}{c}\text { Creep property } \\
\text { (Norton) }\end{array}$} & Constants A (MPa/h) & $5.33 \mathrm{E}-17$ & $4.00 \mathrm{E}-22$ \\
\cline { 2 - 6 } & Stress exponent (n) & 10.4 & \multicolumn{2}{|c}{11.64} \\
\hline
\end{tabular}

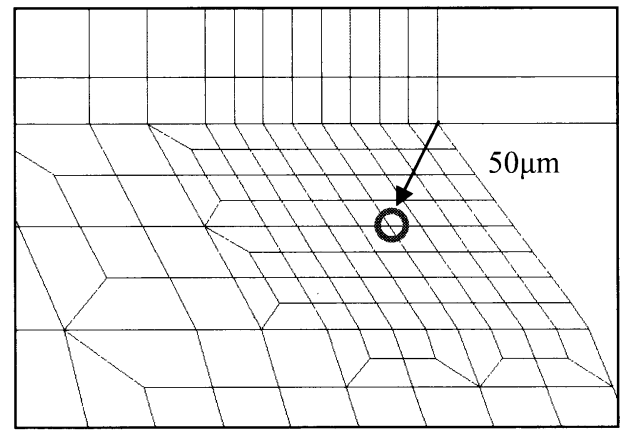

Fig. 8 Measurement point of stress and strain

を测定した ${ }^{10)}$ 。

3.1.1 Sn-3.5Ag-0.75Cuはんだ

三角波の強制変位（変位振幅 $\Delta \delta: 7 \mu \mathrm{m}, 0.01 \mathrm{~Hz}$ ）を与 えた解析結果を Fig. 9 に示す。Fig. 9-(a) は解析と機械的せ ん断疲労試験で得られたはんだ接合部の反力 (RF)で, Fig. 9-(b) は解析で得られたはんだ接合部に生じる相当非線形ひ ずみ $(\varepsilon)$ である。まず, 移動硬化則で解析を行った場合は, はんだ接合部における反力のピークの值 $(25.9 \mathrm{~N})$ は実験結果 と同様にほぼ一定值を保っている。しかし, 等方硬化則で 解析を行った場合は, サイクル進行とともに累積する相当 非線形ひずみによる降伏面の増大が発生し，はんだ接合部 の反力も上昇する。そして, $\mathrm{Sn}-3.5 \mathrm{Ag}-0.75 \mathrm{Cu}$ の場合は 2 サ イクル目から安定した反力が得られた。また, クリープを 考慮せず等方硬化則を用いて弾塑性解析を行う場合は反力 ピーク值が大きく上昇し, Fig. 9-(a)に示している実験と比 較して $40 \%$ 以上増大している。そして示していないが移動 硬化則を用いた弾塑性解析からは移動硬化則を用いたク リープ解析とほぼ同様な結果が得られた。移動硬化則と等 方硬化則の弾塑性クリープ解析で得られた反力と非線形ひ ずみをTable 2 に示す。はんだ接合部における反力のピーク 值は等方硬化の方が移動硬化より約 $13 \%$ 大きく，5サイク ルまでの非線形ひずみ $(\varepsilon)$ においては等方硬化の方で約 $12 \%$ 小さく発生している。また, はんだ接合部の信頼性評価に よく使われる非線形ひずみ振幅 $(\Delta \varepsilon)$ で比較しても， $12 \%$ の

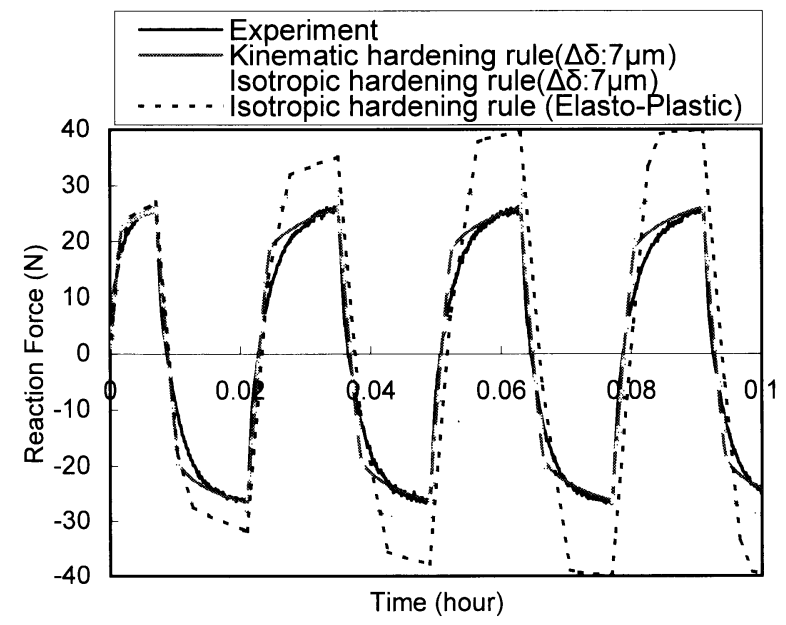

(a) Reaction force of solder joint

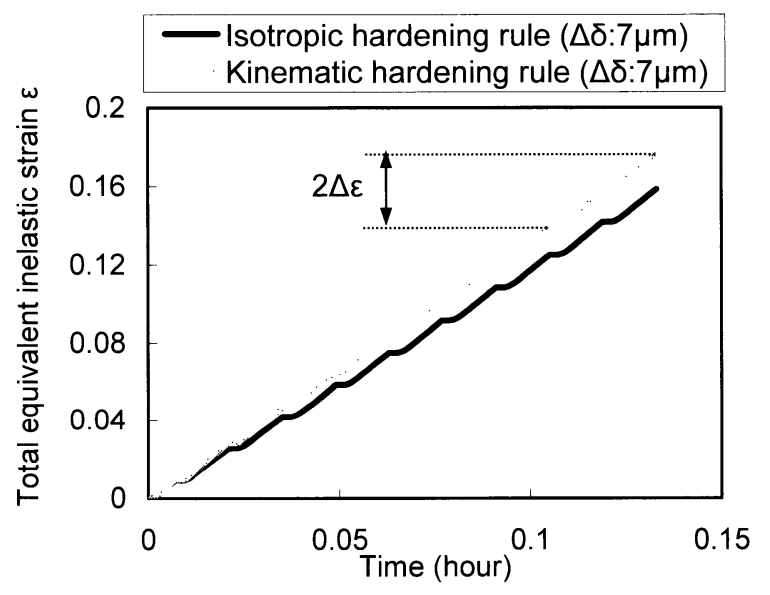

(b) Nonlinear strain of solder joint

Fig. 9 Result of analysis without holding time (Sn3.5Ag-0.75Cu)

Table 2. Reaction force and nonlinear strain by triangular wave

\begin{tabular}{c|c|c|c}
\hline & Iso & Kine & Iso/Kine \\
\hline Peak of RF $(\mathrm{N})$ & 29.2 & 25.9 & 1.13 \\
\hline$\varepsilon$ & 0.145 & 0.165 & 0.88 \\
\hline$\Delta \varepsilon$ & 0.0153 & 0.0173 & 0.88 \\
\hline
\end{tabular}

差が発生している。

15 分間保持を設けた解析結果を Fig. 10 に示す。保持時間 を設けた解析においても保持時間のない解析結果と同様に, 移動硬化則で解析を行った場合は反力のピークの值がほぼ 一定值 $(25.9 \mathrm{~N})$ を保ち実験結果と一致するが, 等方硬化則の 結果ではわずかではあるが, サイクル進行とともに反力の ピーク值が上昇し 2 サイクル目から安定している。保持時 間における応力緩和後の反力の值において実験と解析の誤 差が大きいが，これは試験機の精度が原因であると思われ る。移動硬化則と等方硬化則で得られた反力と非線形ひず みを Table 3 に示す。Table 2 の保持時間がない場合の結果 


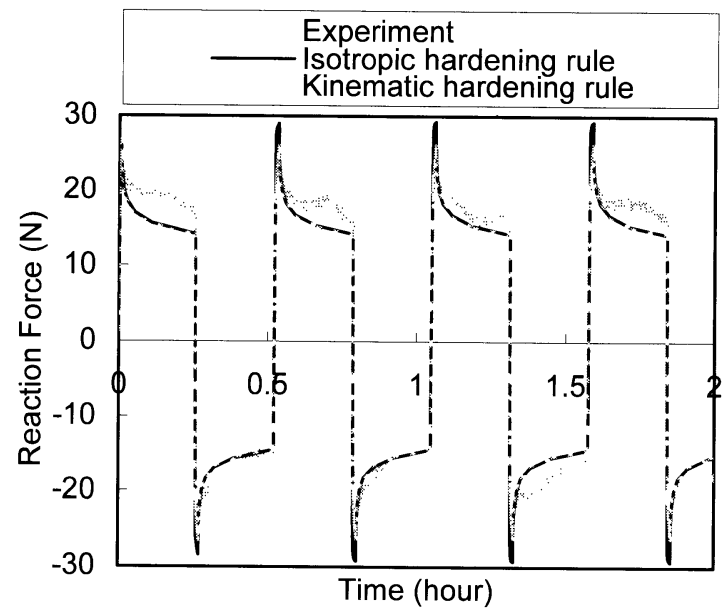

Fig. 10 Reaction force in analysis with 15 minutes holding time

Table 3. Reaction force and nonlinear strain by trapezoid wave with 15 minutes holding time

\begin{tabular}{c|c|c|c}
\hline & Iso & Kine & Iso/Kine \\
\hline Peak of RF $(\mathrm{N})$ & 29.2 & 25.9 & 1.13 \\
\hline$\varepsilon$ & 0.176 & 0.189 & 0.93 \\
\hline$\Delta \varepsilon$ & 0.0186 & 0.0199 & 0.93 \\
\hline
\end{tabular}

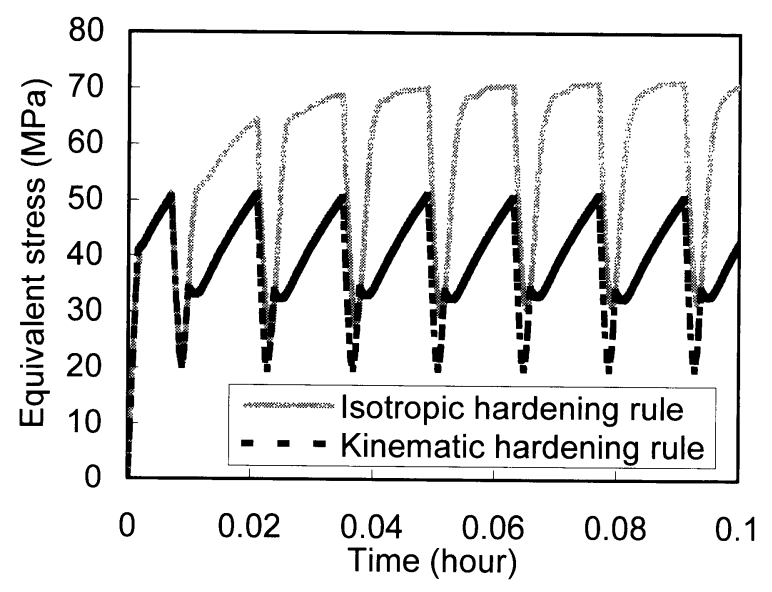

(a) Triangular wave

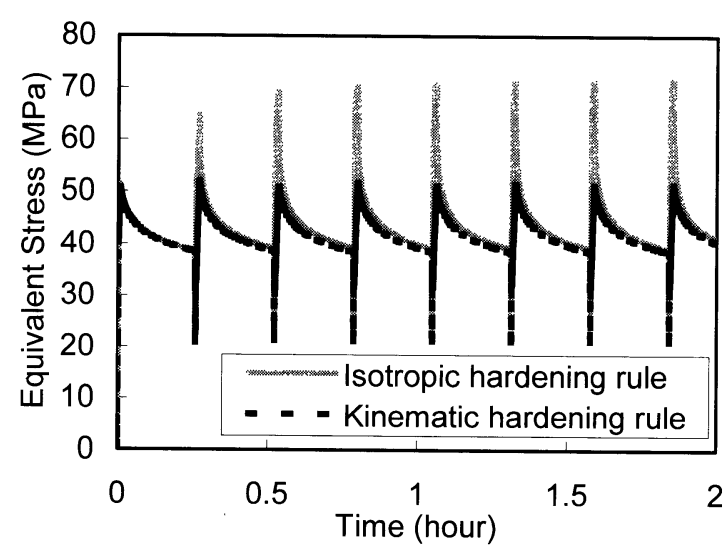

(b) Trapezoid wave with 15 minutes holding time

Fig. 11 Equivalent stress of $\mathbf{S n - 8 Z n - 3 B i}$ solder joint
と比較して移動硬化則と等方硬化則における反力の差は同 じであるが $(13 \%)$, 非線形ひずみや非線形ひずみ振幅の誤 差は保持時間を設けることで7\%に小さくなった。

\subsubsection{Sn-8Zn-3Bi はんだ}

Sn-8Zn-3Bi はんだは鉛フリーはんだ材の中でも高い加工 硬化を示しているため, 他のはんだ材に比べ硬化則の影響 が大きい。Fig. 11 に保持時間のない三角波と15分間の保持 時間を設けた解析のはんだバンプにおける相当応力の履歴 を示す（変位振幅 $\Delta \delta: 7 \mu \mathrm{m}$ )。また, Table 4 と Table 5 に 各解析における最大相当応力, 非線形ひずみを示す。等方 硬化則を用いた解析においては最大相当応力がサイクルの 進行とともに上昇し 3 サイクル以降に安定した值になる。 両硬化則における最大相当応力の䛊差は約 $40 \%$ で Sn$3.5 \mathrm{Ag}-0.75 \mathrm{Cu}$ はんだに比べてその差は大きい。また, Table 4 と Table 5 から最大相当応力の䛊差は保持時間に影響され ないが，非線形ひずみと非線形ひずみ振幅における誤差は 保持時間を設けることで大幅に小さくなり， $7 \%$ まで収まっ た。その理由はFig. 11-(b)に示すように保持時間において クリープひずみが多く発生し，はんだ接合部の応力が十分 に緩和されたためである。

Sn-8Zn-3Bi はんだに関しては15分間保持を設けた解析 において機械的せん断疲労負荷の大きさ, すなわち変位振 幅を $5 \mu \mathrm{m}$ と $9 \mu \mathrm{m}$ に変えて硬化則の影響を検討した。Table 6 と Table 7 にそれぞれ変位振幅を $5 \mu \mathrm{m}$ と $9 \mu \mathrm{m}$ における解 析結果を示す。Table 5, 6,7 から変位振幅が大きくなる之両 硬化則における最大相当応力, 非線形ひずみ, 非線形ひず み振幅の䛊差が小さくなることがわかる。特に変位振幅が $9 \mu \mathrm{m}$ の場合は非線形ひずみ振幅は誤差が $4 \%$ で両硬化則に おいてほぼ一致している。変位振幅が $5 \mu \mathrm{m}$ の場合は非線 形ひずみ振幅の誤差が $15 \%$ であるが，負荷時間を長く（6 分）取ると負荷時にクリープひずみが大きく発生し, 非線

Table 4. Equivalent stress and nonlinear strain by triangular wave $(\Delta \delta=7 \mu \mathrm{m})$

\begin{tabular}{c|c|c|c}
\hline & Iso & Kine & Iso/Kine \\
\hline Equivalent stress & 71.6 & 51 & 1.40 \\
\hline$\varepsilon$ & 0.117 & 0.160 & 0.73 \\
\hline$\Delta \varepsilon$ & 0.0129 & 0.0168 & 0.77 \\
\hline
\end{tabular}

Table 5. Equivalent stress and nonlinear strain by trapezoid wave with 15 minutes holding time

\begin{tabular}{c|c|c|c}
\hline & Iso & Kine & Iso/Kine \\
\hline Equivalent stress & 71.8 & 51.4 & 1.40 \\
\hline$\varepsilon$ & 0.153 & 0.176 & 0.87 \\
\hline$\Delta \varepsilon$ & 0.0173 & 0.0185 & 0.93 \\
\hline
\end{tabular}


Table 6. Equivalent stress and nonlinear strain by trapezoid wave $(\Delta \delta=5 \mu \mathrm{m})$

\begin{tabular}{c|c|c|c}
\hline & Iso & Kine & Iso/Kine \\
\hline Equivalent stress & 69.2 & 47.8 & 1.45 \\
\hline$\varepsilon$ & 0.095 & 0.115 & 0.83 \\
\hline$\Delta \varepsilon$ & 0.0103 & 0.0122 & 0.85 \\
\hline
\end{tabular}

Table 7. Equivalent stress and nonlinear strain by trapezoid wave $(\Delta \delta=9 \mu \mathrm{m})$

\begin{tabular}{c|c|c|c}
\hline & Iso & Kine & Iso/Kine \\
\hline Equivalent stress & 73.3 & 54.8 & 1.34 \\
\hline$\varepsilon$ & 0.212 & 0.233 & 0.91 \\
\hline$\Delta \varepsilon$ & 0.0236 & 0.0245 & 0.96 \\
\hline
\end{tabular}

Table 8. Equivalent stress and nonlinear strain (in trapezoid wave of $5 \mu \mathrm{m}$ amplitude with 6 minutes loading time)

\begin{tabular}{c|c|c|c}
\hline & Iso & Kine & Iso/Kine \\
\hline Equivalent stress & 58.9 & 47 & 1.25 \\
\hline$\varepsilon$ & 0.101 & 0.116 & 0.87 \\
\hline$\Delta \varepsilon$ & 0.0109 & 0.0122 & 0.89 \\
\hline
\end{tabular}

形ひずみ振幅の誤差は $11 \%$ と大幅に小さくなる(Table 8)。 両硬化則における非線形ひずみの誤差の発生は等方硬化 による応力の上昇が原因である。Fig. 12 に両硬化則におけ る Sn-8Zn-3Bi はんだ接合部のせん断ひずみの分布を示す。 ひずみ集中部（領域 A，C）においては等方硬化則(A)より 移動硬化則 (C)で発生するひずみが大きいが，非ひずみ集 中部（領域 B，D）では移動硬化則 (D) より等方硬化則 (B) でひずみが大きく発生している。すなわち，等方硬化の場 合はひずみがはんだ接合部の全体に分散して生じるため, ひずみ集中部の值が低下する。

\section{2 温度サイクル解析}

ここではさらに $\mathrm{Sn}-3.5 \mathrm{Ag}-0.75 \mathrm{Cu}$ と $\mathrm{Sn}-8 \mathrm{Zn}-3 \mathrm{Bi}$ 鉛フリー はんだに対して熱疲労サイクル解析の応力・非線形ひずみ 評価における硬化則についても検討を行った。はんだバン プに熱澎張差によるミスマッチを与えるため, シリコン

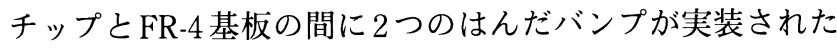
BGA 試験片を解析に用いた。解析モデルをFig. 13 に, 解 析で用いた各温度におけるはんだの材料特性を Table 9 に 示す。温度範囲は $-40^{\circ} \mathrm{C} \sim 125^{\circ} \mathrm{C}$ と $-20^{\circ} \mathrm{C} \sim 85^{\circ} \mathrm{C}$ で, 温度 変化時間は 3 分で, ピーク温度における保持時間は 15 分で

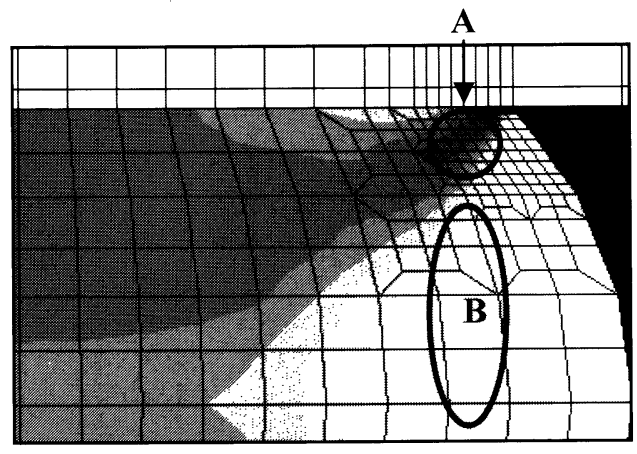

(a) In isotropic hardening rule

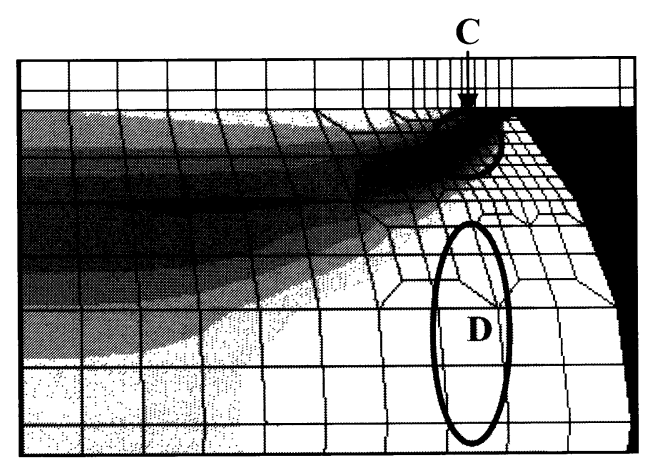

(b) In Kinematic hardening rule

Fig. 12 Distribution of shear strain in $\mathrm{Sn}-8 \mathrm{Zn}-3 \mathrm{Bi}$ solder joint

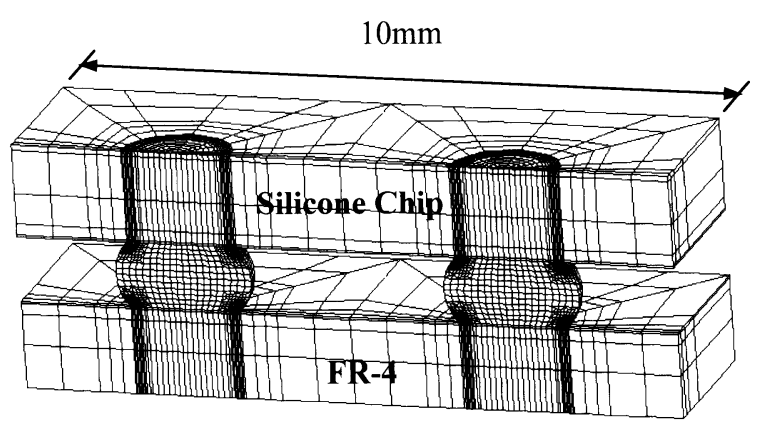

Fig. 13 Analysis model for thermal loading

ある。解析は 4サイクルまで行い, Fig. 14 に示すように非 線形ひずみ振幅 $(\Delta \varepsilon)$ は 4 サイクル目の非線形ひずみの振幅 を測定した。

まず， $-40{ }^{\circ} \mathrm{C} \sim 125^{\circ} \mathrm{C}$ の温度範囲の $\mathrm{Sn}-3.5 \mathrm{Ag}-0.75 \mathrm{Cu}$ と Sn-8Zn-3Bi はんだの解析結果をそれぞれ Table 10 と Table 11 に示す。 $-40^{\circ} \mathrm{C} \sim 125^{\circ} \mathrm{C}$ の温度範囲でははんだ材に関係 せず，両硬化則における最大相当応力と非線形ひずみの誤 差は $10 \%$ 以下である。 $-20^{\circ} \mathrm{C} \sim 85^{\circ} \mathrm{C}$ の温度範囲でも非線形 ひずみ振幅の誤差 $15 \%$ 程度で収まっている (Table 12, 13)。 また, 温度サイクル解析においても温度変化時間を若干長 く（10 分）取ることで, 両硬化則における最大相当応力の 差を $10 \%$ 程度で収めることが可能である(Table 14)。 
Table 9. Material properties of each solder material used in thermal cycle analysis

\begin{tabular}{|c|c|c|c|c|c|c|c|c|}
\hline \multirow{3}{*}{$\begin{array}{c}\text { Temperature } \\
{ }^{\circ} \mathrm{C}\end{array}$} & \multicolumn{4}{|c|}{$\mathrm{Sn}-3.5 \mathrm{Ag}-0.75 \mathrm{Cu}$} & \multicolumn{4}{|c|}{$\mathrm{Sn}-8 \mathrm{Zn}-3 \mathrm{Bi}$} \\
\hline & \multicolumn{2}{|c|}{ Plastic property } & \multicolumn{2}{|c|}{ Creep property (Norton) } & \multicolumn{2}{|c|}{ Plastic property } & \multicolumn{2}{|c|}{ Creep property (Norton) } \\
\hline & Strain & Stress $(\mathrm{MPa})$ & $\mathrm{A}(\mathrm{MPa} / \mathrm{h})$ & $\mathrm{n}$ & Strain & Stress $(\mathrm{MPa})$ & $\mathrm{A}(\mathrm{MPa} / \mathrm{h})$ & $\mathrm{n}$ \\
\hline \multirow{2}{*}{-40} & 0.0000 & 29.0 & \multirow{2}{*}{$5.09 \mathrm{E}-22$} & \multirow{2}{*}{13.19} & 0.00 & 58.0 & \multirow{2}{*}{$8.43 \mathrm{E}-32$} & \multirow{2}{*}{16.13} \\
\hline & 0.0214 & 48.4 & & & 0.03 & 113.0 & & \\
\hline \multirow{2}{*}{-20} & 0.0000 & 27.5 & \multirow{2}{*}{$1.24 \mathrm{E}-20$} & \multirow{2}{*}{12.54} & 0.00 & 53.0 & \multirow{2}{*}{$1.30 \mathrm{E}-28$} & \multirow{2}{*}{14.66} \\
\hline & 0.0214 & 45.9 & & & 0.03 & 103.0 & & \\
\hline \multirow{2}{*}{0} & 0.0000 & 25.0 & \multirow{2}{*}{$3.00 \mathrm{E}-19$} & \multirow{2}{*}{11.90} & 0.00 & 103.0 & \multirow{2}{*}{$2.00 \mathrm{E}-25$} & \multirow{2}{*}{13.19} \\
\hline & 0.0214 & 41.7 & & & 0.03 & 86.0 & & \\
\hline \multirow{2}{*}{20} & 0.0000 & 23.0 & \multirow{2}{*}{$7.29 \mathrm{E}-18$} & \multirow{2}{*}{11.25} & 0.00 & 37.0 & \multirow{2}{*}{$3.08 \mathrm{E}-22$} & \multirow{2}{*}{11.72} \\
\hline & 0.0214 & 38.3 & & & 0.03 & 73.0 & & \\
\hline \multirow{2}{*}{40} & 0.0000 & 21.0 & \multirow{2}{*}{$1.77 \mathrm{E}-16$} & \multirow{2}{*}{10.64} & 0.00 & 32.0 & \multirow[b]{2}{*}{$4.75 \mathrm{E}-19$} & \multirow[b]{2}{*}{10.25} \\
\hline & 0.0214 & 35.0 & & & 0.03 & 59.0 & & \\
\hline \multirow{2}{*}{60} & 0.0000 & 18.9 & & & 0.00 & 25.0 & & \\
\hline & 0.0214 & 31.6 & $4.30 \mathrm{E}-15$ & 9.97 & 0.03 & 46.0 & 7.31E-16 & 8.78 \\
\hline & 0.0000 & 17.0 & & & 0.00 & 19.0 & & \\
\hline 80 & 0.0214 & 28.3 & $1.04 \mathrm{E}-13$ & 9.32 & 0.03 & 34.0 & $1.13 \mathrm{E}-12$ & 7.31 \\
\hline & 0.0000 & 15.2 & & & 0.00 & 17.0 & & \\
\hline 100 & 0.0214 & 25.3 & $2.54 \mathrm{E}-12$ & 8.68 & 0.03 & 28.0 & $1.74 \mathrm{E}-09$ & 5.84 \\
\hline & 0.0000 & 13.4 & & & 0.00 & 15.0 & & \\
\hline 120 & 0.0214 & 22.4 & $6.16 \mathrm{E}-11$ & 8.04 & 0.03 & 22.0 & $2.68 \mathrm{E}-06$ & 4.37 \\
\hline & 0.0000 & 12.9 & & & 0.00 & 14.0 & & \\
\hline 130 & 0.0214 & 21.6 & $3.04 \mathrm{E}-10$ & 7.72 & 0.03 & 20.0 & $1.05 \mathrm{E}-04$ & 3.64 \\
\hline
\end{tabular}

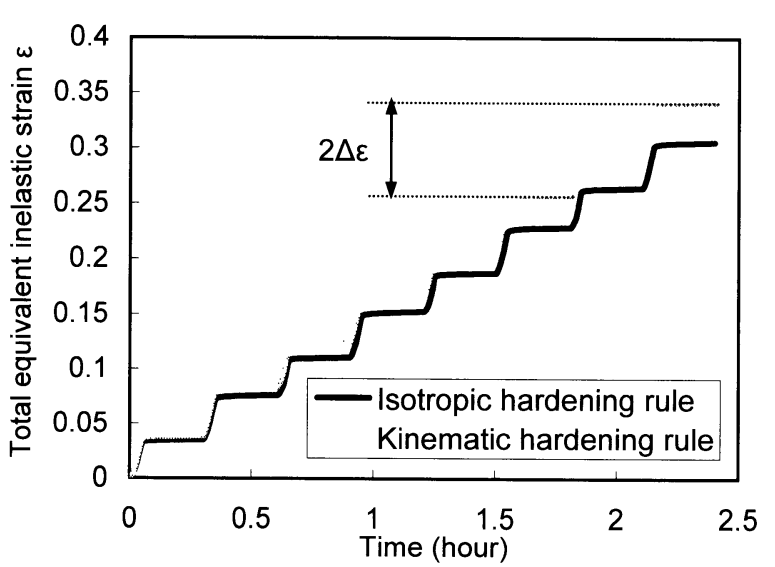

Fig. 14 Nonlinear strain of $\mathrm{Sn}-3.5 \mathrm{Ag}-0.75 \mathrm{Cu}$ solder joint $\left(-40^{\circ} \mathrm{C}\right.$ to $\left.125^{\circ} \mathrm{C}\right)$

\section{3 解析時間}

Table 15 に各解析におけるCPU Time を示す。Table 15 の CPU Timeはそれぞれの解析の平均時間で, 解析を行った パソコンの性能はXEONの $1.8 \mathrm{GHz} * 2 \mathrm{CPU}, 2.3 \mathrm{~GB}$ Memory である。また，機械的負荷解析は 5 サイクル，温度サイク ル解析は 4 サイクルまでの解析時間である。移動硬化則を 用いた場合は収束性が悪く, 機械的負荷の解析では約 5 倍, 温度サイクルの解析では約 3 倍程度等方硬化則を用いた計 算より計算時間が長くかかる。

\section{4. 考 察}

繰り返し機械的せん断変位や温度サイクル負荷を受ける はんだ接合部の応力・非線形ひずみ評価におけるはんだ材 
Table 10. Equivalent stress and nonlinear strain of $\mathrm{Sn}-3.5 \mathrm{Ag}-0.75 \mathrm{Cu}\left(-40^{\circ} \mathrm{C}\right.$ to $\left.125^{\circ} \mathrm{C}\right)$

\begin{tabular}{c|c|c|c}
\hline & Iso & Kine & Iso/Kine \\
\hline Equivalent stress & 41.1 & 37.7 & 1.09 \\
\hline$\varepsilon$ & 0.306 & 0.339 & 0.90 \\
\hline$\Delta \varepsilon$ & 0.0383 & 0.0423 & 0.91 \\
\hline
\end{tabular}

Table 11. Equivalent stress and nonlinear strain of $\mathrm{Sn}-8 \mathrm{Zn}-3 \mathrm{Bi}$ solder $\left(-40^{\circ} \mathrm{C}\right.$ to $\left.125^{\circ} \mathrm{C}\right)$

\begin{tabular}{c|c|c|c}
\hline & Iso & Kine & Iso/Kine \\
\hline Equivalent stress & 79.5 & 79.2 & 1.0 \\
\hline$\varepsilon$ & 0.268 & 0.295 & 0.91 \\
\hline$\Delta \varepsilon$ & 0.0328 & 0.0352 & 0.93 \\
\hline
\end{tabular}

Table 12. Equivalent stress and nonlinear strain of $\mathrm{Sn}-3.5 \mathrm{Ag}-0.75 \mathrm{Cu}\left(-20^{\circ} \mathrm{C}\right.$ to $\left.85^{\circ} \mathrm{C}\right)$

\begin{tabular}{c|c|c|c}
\hline & Iso & Kine & Iso/Kine \\
\hline Equivalent stress & 36.5 & 31.1 & 1.17 \\
\hline$\varepsilon$ & 0.145 & 0.165 & 0.88 \\
\hline$\Delta \varepsilon$ & 0.0183 & 0.0208 & 0.88 \\
\hline
\end{tabular}

Table 13. Equivalent stress and nonlinear strain of $\mathrm{Sn}-8 \mathrm{Zn}-3 \mathrm{Bi}$ solder $\left(-20^{\circ} \mathrm{C}\right.$ to $\left.85^{\circ} \mathrm{C}\right)$

\begin{tabular}{c|c|c|c}
\hline & Iso & Kine & Iso/Kine \\
\hline Equivalent stress & 70.9 & 60.3 & 1.18 \\
\hline$\varepsilon$ & 0.124 & 0.148 & 0.84 \\
\hline$\Delta \varepsilon / 2$ & 0.0152 & 0.0179 & 0.85 \\
\hline
\end{tabular}

Table 14. Equivalent stress and nonlinear strain of $\mathrm{Sn}-8 \mathrm{Zn}-3 \mathrm{Bi}$ solder $\left(-20^{\circ} \mathrm{C}\right.$ to $85^{\circ} \mathrm{C}$ with 10 minutes temperature change time)

\begin{tabular}{c|c|c|c}
\hline & Iso & Kine & Iso/Kine \\
\hline Equivalent stress & 65 & 59 & 1.10 \\
\hline$\varepsilon$ & 0.127 & 0.149 & 0.85 \\
\hline$\Delta \varepsilon / 2$ & 0.0156 & 0.0182 & 0.86 \\
\hline
\end{tabular}

Table 15. CPU Time in each analysis

\begin{tabular}{l|c|c|c}
\hline & Kine (hour) & Iso (hour) & Kine/Iso \\
\hline $\begin{array}{l}\text { Mechanical fatigue analysis } \\
\text { (element: 6336, node: } 7328)\end{array}$ & 31 & 6.3 & 4.92 \\
\hline $\begin{array}{l}\text { Thermal cycle analysis } \\
\text { (element: } 12672, \text { node: } 14601)\end{array}$ & 46 & 16 & 2.87 \\
\hline
\end{tabular}

の硬化則の影響について調べた結果, 機械的せん断負荷に おいては，保持時間を設ける場合は移動硬化則と等方硬化 則を用いた解析結果から得られたはんだ接合部の非線形ひ ずみ振幅の差は $10 \%$ 程度である (Table 3, 5, 7,8)。温度サイ クル解析においても，はんだ材の種類と関係なく両硬化則 における非線形ひずみ振幅の䛊差は大きくても $15 \%$ である (Table 13)。はんだ接合部の疲労寿命評価には Coffin-Manson 則が主に用いられているが，Coffin-Manson則でははん だ接合部の疲労寿命とはんだ接合部に発生する非線形ひず みが両対数関係で表されている(1) 4),11,12)。また，電子デバ イスはんだ接合部の疲労寿命におけるばらつきを考えると, 非線形ひずみ振幅の $10 \%$ ～ $15 \%$ 以下の䛊差は接合部の疲労 寿命評価にそれほど大きな影響を与えないと思われる。

機械的繰り返しせん断負荷の解析において，はんだ接合 部の応力を評価する場合は $\mathrm{Sn}-3.5 \mathrm{Ag}-0.75 \mathrm{Cu}$ はんだでは両 硬化則における最大相当応力の差が十数パーセントである (Table 2,3) が，加工硬化の大きいSn-8Zn-3Biはんだでは両 硬化則に打ける最大相当応力の差が $40 \%$ と大きくなる (Table 5)。また, 温度サイクル解析でははんだ接合部の応 力評価における両硬化則の誤差が十数パーセント生じてい る(Table 10 14)。このように応力の評価において両硬化則 の差が大きい理由は, 変位または温度の負荷時において等 方硬化による影響が大きく現れているためである。著者ら は負荷時においての等方硬化の影響をなくし，また解析の 収束性を向上させるため, 移動硬化則を適用し, 負荷時に はクリープを考慮せず保持時間のみクリープを考慮した弾 塑性・クリープ解析について検討を行った。Table 16 之 Table 17 はそれぞれ Sn-8Zn-3Bi はんだの機械的負荷解析と 温度サイクル解析の結果である。非線形ひずみの誤差はわ ずか数パーセントで, 応力の評価における誤差は $10 \%$ 以下 の精度のよい結果が得られた。負荷時に移動硬化則を考慮 することで応力の誤差が小さくなり, 保持時のクリープ変 形によって応力が十分緩和され，非線形ひずみの評価にお いても精度が良くなった。解析に使用した塑性特性が実際 にはんだバンプに発生するひずみ速度に近い值であるため, 負荷時にクリープが考慮されなくても応力の䛊差が大きく ならない結果となった。このように負荷時にクリープを考 慮しなければ収束性も特に問題とならないため, 計算時間 も短縮できる。

また, 機械的疲労試験と温度サイクル試験において一般 
Table 16. Equivalent stress and nonlinear strain of Sn-8Zn-3Bi solder (by trapezoid wave $\Delta \delta=$ $7 \mu \mathrm{m})$

\begin{tabular}{c|c|c|c}
\hline & $\begin{array}{c}\text { Kine I (Partial } \\
\text { Elasto-plasticity/Creep) }\end{array}$ & $\begin{array}{c}\text { Kine II (Full } \\
\text { Elasto-plasticity/Creep) }\end{array}$ & Kine I/Kine II \\
\hline $\begin{array}{c}\text { Equivalent } \\
\text { stress }\end{array}$ & 52 & 51.4 & 1.01 \\
\hline$\varepsilon$ & 0.1754 & 0.1759 & 0.99 \\
\hline$\Delta \varepsilon / 2$ & 0.01846 & 0.01852 & 0.99 \\
\hline
\end{tabular}

Table 17. Equivalent stress and nonlinear strain of $\mathrm{Sn}-8 \mathrm{Zn}-3 \mathrm{Bi}$ solder $\left(-40^{\circ} \mathrm{C}\right.$ to $\left.125^{\circ} \mathrm{C}\right)$

\begin{tabular}{c|c|c|c}
\hline & $\begin{array}{c}\text { Kine I (Partial } \\
\text { Elasto-plasticity/Creep) }\end{array}$ & $\begin{array}{c}\text { Kine II (Full } \\
\text { Elasto-plasticity/Creep) }\end{array}$ & Kine I/Kine II \\
\hline $\begin{array}{c}\text { Equivalent } \\
\text { stress }\end{array}$ & 87.0 & 79.2 & 1.10 \\
\hline$\varepsilon$ & 0.293 & 0.295 & 0.99 \\
\hline$\Delta \varepsilon / 2$ & 0.0342 & 0.0352 & 0.97 \\
\hline
\end{tabular}

に行われる試験範囲内であれば，はんだ周辺の構造や剛性， 負荷条件が若干変わっても上記の結果は大きく変わらない と考えられる。

\section{5. まとめ}

本研究では鉛フリーはんだ接合部の機械的疲労試験と有 限要素法 $(\mathrm{FEM})$ 解析を用いて, 鉛フリーはんだ接合部の応 力・非線形ひずみの評価においての硬化則の影響を調べた。 機械的せん断疲労試験の結果から, Sn-3.5Ag-0.75Cu と Sn-8Zn-3Bi はんだは移動硬化の硬化特性を示すことが確認 された。

機械的負荷解析において, Sn-3.5Ag-0.75Cuはんだは加 工硬化がそれほど大きくないため, はんだ接合部の非線形 ひずみ振幅の評価における両硬化則の誤差が小さい $(10 \%)$ が，加工硬化の大きい Sn-8Zn-3Bi はんだではその誤差は 若干上昇し，15\%に収まる。温度サイクル解析では温度範 囲によって，非線形ひずみ振幅の両硬化則における誤差が 変わるが大きくても $15 \%$ である。しかし，はんだ接合部の 非線形ひずみ振幅の評価において，10\%～15\% 以下の䛊差 は接合部の疲労寿命評価にそれほど大きな影響を与えない と考えられるので, $\mathrm{Sn}-3.5 \mathrm{Ag}-0.75 \mathrm{Cu}$ と $\mathrm{Sn}-8 \mathrm{Zn}-3 \mathrm{Bi}$ 鉛フ リーはんだ接合部の有限要素解析において, 解析環境に注 意すれば移動硬化のかわりに等方硬化を用いてはんだ接合 部の非線形ひずみを評価することが可能であると考えられ る。
はんだ接合部の応力を評価する場合は，機械的負荷解析 でははんだ材料によって両硬化則の䛊差が $40 \%$ まで大きく なる。また, 温度サイクル解析においても両硬化則の誤差 が十数パーセント発生した。しかし，機械的負荷解析と温 度サイクル解析において移動硬化則を適用し，負荷時には クリープを考慮せず保持時間のみクリープを考慮した弾塑 性・クリープ解析を行うと, 収束性に問題なく応力・非線 形ひずみの評価における誤差が $10 \%$ 以下の精度のよい結果 が得られる。

(2003.8.17-受理)

\section{文献}

1) Q. Yu and M. Shiratori: "Fatigue-Strength Prediction of MicroElectronics Solder Joints under Thermal Cyclic Loading", IEEE Trans. Comp., Hybrids, Manufact. Technol., Vol. 20, No. 3, pp. 266-273, 1997

2) M. Mukai, T. Kawakami, K. Takahashi, K. Kishimoto and T. Shibuya: "Thermal Fatigue Life of Solder Bumps in BGA", JSME International A, Vol. 41, No. 2, p. 260, 1998

3) T. J. Kilinski, J. R. Lesniak and B. I. Sandor: "Modern Approaches to Fatigue Life Prediction of SMT Solder Joints", Solder Joint Reliability: Theory and Applications, Ed. by J. H. Lau, pp. 384-390, 1991

4) H. L. J. Pang, Y. T. Kwok and C. W. SeeToh: "Temperature Cycling Fatigue Analysis of Fine Pitch Solder Joints": Proc. of Interpack '97, Vol. 2, pp. 1495-1500, 1997

5) P. Biocca: “Global Update on Lead-Free Solders”, Proc. Surface Mount International, pp. 705-709, 1998

6）森 孝男, 佐山利彦, 于 強, 青木秀明, 垣野 学: “鉛 フリーはんだの非線形変形物性”, mate2002, pp. 227-230, 2002

7) Q. Yu, D.-S. Kim, M. Shiratori, M. Kakino and H. Aoki: “The Effect of Intermetallic Compound on Thermal Fatigue Reliability of Lead-Free Solder Joints”, Proceedings of InterPACK '01, IPACK2001-15751, 2001

8) 石川博將: “固体の非線形力学”, 養賢堂, p. 15, 2000

9）伊東伸孝, 作山誠樹：“鉛フリーはんだの機械特性”, 鉛フ リーはんだ接合部の信頼性評価, pp. 1-8, 信頼性解析技術 シンポジウム, エレクトロニクス実装学会, 2001

10) 于 強, 白鳥正樹：“BGAはんだ接合部の形状を考慮した 疲労寿命評価”, エレクトロニクス実装学会誌, Vol. 1, No. 4, pp. 278-283, 1998

11) S. S. Manson: "Interfaces between Fatigue Creep and Fracture”, Int. J. of Fracture Mechanics, Vol. 2, No. 1, pp. 327-363, 1966

12) S. S. Manson: "Thermal Stress and Low Cycle Fatigue", McGrow-Hill Book Company, New York, 1996 